Eliane Ignotti'

Joaquim Gonçalves Valente"

Karla Maria Longo'"I

Saulo Ribeiro Freitas ${ }^{\text {III }}$

Sandra de Souza Hacon ${ }^{\mathrm{IV}}$

Paulo Artaxo Netto $v$
Departamento de Enfermagem. Instituto de Ciências Naturais e Tecnológicas. Universidade do Estado de Mato Grosso Cáceres, MT, Brasil

Pós-Graduação em Epidemiologia e em Saúde Pública. Departamento de Epidemiologia. ENSP. Rio de Janeiro, RJ, Brasil

III Divisão de Geofísica Espacial. Instituto Nacional de Pesquisas Espaciais. São José dos Campos, SP, Brasil

Iv Pós-Graduação em Saúde Pública e Meio Ambiente. Departamento de Endemias Samuel Pessoa. Escola Nacional de Saúde Pública Sérgio Arouca (ENSP). Rio de Janeiro, RJ, Brasil

Instituto de Física. Universidade de São Paulo. São Paulo, SP, Brasil

Correspondence:

Eliane Ignotti

Av. São João S/N, Cavalhada

78200-000 Cáceres, MT, Brasil

E-mail: eliane.ignotti@cnpq.br

\section{Impact on human health of particulate matter emitted from burnings in the Brazilian Amazon region}

\section{Impactos na saúde humana de partículas emitidas por queimadas na Amazônia brasileira}

\begin{abstract}
OBJECTIVE: To analyze the impact on human health of exposure to particulate matter emitted from burnings in the Brazilian Amazon region.

METHODS: This was an ecological study using an environmental exposure indicator presented as the percentage of annual hours ( $\mathrm{AH} \%)$ of $\mathrm{PM}_{25}$ above $80 \mu \mathrm{g} / \mathrm{m}^{3}$. The outcome variables were the rates of hospitalization due to respiratory disease among children, the elderly and the intermediate age group, and due to childbirth. Data were obtained from the National Space Research Institute and the Ministry of Health for all of the microregions of the Brazilian Amazon region, for the years 2004 and 2005. Multiple regression models for the outcome variables in relation to the predictive variable $\mathrm{AH} \%$ of $\mathrm{PM}_{2.5}$ above $80 \mu \mathrm{g} / \mathrm{m}^{3}$ were analyzed. The Human Development Index (HDI) and mean number of complete blood counts per 100 inhabitants in the Brazilian Amazon region were the control variables in the regression analyses.
\end{abstract}

RESULTS: The association of the exposure indicator (AH\%) was higher for the elderly than for other age groups $(\beta=0.10)$. For each $1 \%$ increase in the exposure indicator there was an increase of $8 \%$ in child hospitalization, $10 \%$ in hospitalization of the elderly, and 5\% for the intermediate age group, even after controlling for HDI and mean number of complete blood counts. No association was found between the $\mathrm{AH} \%$ and hospitalization due to childbirth.

CONCLUSIONS: The indicator of atmospheric pollution showed an association with occurrences of respiratory diseases in the Brazilian Amazon region, especially in the more vulnerable age groups. This indicator may be used to assess the effects of forest burning on human health.

DESCRIPTORS: Hospitalization. Respiratory Tract Diseases. Air Pollutants. Wildfire. Ecological Studies. Fine Particulate Matter. 


\section{RESUMO}

OBJETIVO: Analisar o impacto à saúde humana pela exposição ao material particulado das emissões de queimadas na Amazônia brasileira.

MÉTODOS: Estudo ecológico utilizando o indicador de exposição ambiental apresentado como percentagem anual de horas $(\mathrm{AH} \%)$ de $\mathrm{PM}_{2,5}$ acima de 80 $\mu \mathrm{g} / \mathrm{m}^{3}$ e como desfecho taxas de hospitalização por doenças respiratórias em crianças, idosos e grupos etários intermediários e taxas de hospitalização por parto. Os dados foram obtidos do Instituto Nacional de Pesquisas Espaciais e do Ministério da Saúde para todas as microrregiões da Amazônia Brasileira, nos anos 2004 e 2005 . Foram analisados modelos de regressão múltipla das variáveis de desfecho com a variável preditora $\mathrm{AH} \%$ acima de $80 \mu \mathrm{g} / \mathrm{m}^{3}$ para $\mathrm{PM}_{2,5}$. O Índice de Desenvolvimento Humano (IDH) e o número médio de hemogramas por 100 habitantes na região da Amazônia brasileira foram variáveis de controle nas análises de regressão.

RESULTADOS: Observou-se maior associação do indicador de exposição $(\mathrm{AH} \%)$ para os idosos do que para outros grupos etários $(\beta=0,10)$. Para cada ponto percentual de aumento no indicador de exposição, houve aumento de $10 \%$ na taxa de hospitalização de idosos, $8 \%$ em internações de crianças, e $5 \%$ para a faixa etária intermediária, mesmo ajustando por IDH e número médio de hemogramas. Não foi encontrada associação entre $\mathrm{AH} \%$ e a taxa de hospitalização por parto.

CONCLUSÕES: O indicador de poluição atmosférica mostrou associação com a ocorrência de doenças respiratórias, em especial nos grupos etários mais vulneráveis da Amazônia brasileira, podendo ser utilizado na abordagem dos efeitos da queima das florestas na saúde humana.

DESCRITORES: Hospitalização. Doenças Respiratórias. Poluentes do Ar. Incêndios Florestais. Estudos Ecológicos. Material Particulado Fino.

\section{INTRODUCTION}

Biomass burning is a key issue in terms of air pollution emissions in large areas of South America, and in particular in the Amazon Basin. Large emissions of trace gases and aerosols have significant negative health impacts during the dry season. High concentrations of particulate matter occur typically between July and October, and are mostly located around the "arc of deforestation" in the southern and eastern parts of the basin. ${ }^{3,4}$

The airborne concentration of particulate matter is an important environmental indicator of regional air pollution. Fine particles, smaller than 2.5 micrometers, are emitted through biomass burning, and have relatively long resident time in the atmosphere (around two weeks). These particles can be transported over long distances ${ }^{2}$ and consequently have a regional impact that covers a large area of South America. ${ }^{2,21}$ Air quality over this large region is severely affected, with levels of air pollution much higher than the ambient air quality standards, because of the fine particle size in the smoke from biomass burning. ${ }^{2}$
Over recent years, numerous studies worldwide have found correlations between levels of particulate matter and human respiratory problems, using different outcomes such as emergency room visits, hospital admissions, reduction of pulmonary function and elementary school absences. . $^{511,14,20,22}$ Other studies that have investigated this correlation have used mortality rate as an endpoint associated with respiratory and cardiovascular diseases. ${ }^{1}$ Smoke from biomass burning is particularly important because of its ability to deposit deep into the lungs. ${ }^{16}$ Children under five years of age and adults of 64 years and over have been described in the literature as being significantly affected by exposure to atmospheric pollution. ${ }^{5,18,22}$ Despite the importance of the health impact issue, setting up permanent air quality monitoring networks in the entire Brazilian Amazon region and vicinity would be prohibitively expensive, and impractical because of logistical constraints.

Several studies on the effect of air pollution on human health already exist. In Brazil, most studies were carried out in urban areas such as São Paulo. 
In most cases, much of the evidence on the effects of air pollution on respiratory health was based on timeseries analyses. ${ }^{8,14}$ In urban areas, chronic exposure is usually observed, but the smoke from biomass burning represents acute exposure that, depending on the length of the dry season, may last for around three months a year. Consequently, it can be assumed that exposure to the smoke from biomass burning probably produces intensities of effects that differ from exposure to urban air pollution. ${ }^{15}$ In fact, values as high as $400 \mu \mathrm{g} / \mathrm{m}^{3}$ of $\mathrm{PM}_{10}$ have been reported in some areas of the Amazon region during the dry season.,

The Amazon region encompasses an area of about 5 million $\mathrm{km}^{2}$ with an estimated population of 24 million inhabitants, distributed among more than 805 municipalities, which make up a total of 107 microregions. ${ }^{\text {a }}$ The geographical, sociodemographic, environmental and meteorological characteristics of the Amazon region suggest that there is a need for a new methodological approach towards environmental indicators.

The objective of the present study was to analyze the impact on human health of exposure to particulate matter emissions from biomass burning in the Brazilian Amazon region.

\section{METHODS}

The present study complements the Large-Scale Biosphere-Atmosphere Experiment in the Amazon region (LBA) and the Millennium Institute network project: " "Evaluation of the Effects of Biomass Burning on Human Health in the Brazilian Amazon Region", which was carried out between 2006 and 2008.

This ecological study used a new methodological approach to define an environmental exposure indicator. The exposure indicator proposed in this study is based on the annual number of measurements of $\mathrm{PM}_{2.5}$ above the concentration of $80 \mu \mathrm{g} / \mathrm{m}^{3}$ divided by the total number of measurements during the year in question. This indicator consists of an annual percentage rate. The ratio is expressed as the percentage of annual hours $(\mathrm{AH} \%)$ during which $\mathrm{PM}_{2.5}$ is above the threshold of $80 \mu \mathrm{g} / \mathrm{m}^{3}$.

$$
\mathrm{AH} \%=\left(\frac{\sum \mathrm{H}>80 \mu \mathrm{g} / \mathrm{m}^{3}}{\sum \mathrm{H}}\right) \times 100
$$

* $\mathrm{H}$ - number of hours over which $\mathrm{PM}_{2.5}$ is measured during the year.

The levels of exposure were estimated for the years 2004 and 2005 and the morbidity rates for respiratory diseases (RD) were calculated for the same period. This was the most recent and largest period for which a complete estimated database for $\mathrm{PM}_{2.5}$ was available.

The spatial units of analyses were microregions of the Brazilian Amazon region within the northern states (Acre, Amazonas, Amapá, Rondônia, Roraima and Tocantins), along with the states of Mato Grosso and Maranhão. Out of the total of 805 municipalities, 729 $(90.3 \%)$ had less than 5,000 inhabitants in 2005. Each microregion includes at least five municipalities. We used the 107 microregions, thereby aggregating the municipalities, because this reduced the variability of the hospitalization rates and because there is usually one reference hospital for each microregion in the Brazilian Amazon region.

The environmental exposure indicator for the impact of biomass burning was derived from a simulation using the Coupled aerosol and trace gas transport model for the Brazilian development of the Regional Atmospheric Modeling System ${ }^{7}$ Model (CATTBRAMS). This model is an online atmospheric emission and transport model that takes into account atmospheric dynamics. The emissions from biomass burning for several trace gases and aerosol particles were obtained from satellite observations of fires, using the 3BEM (Brazilian Biomass Burning Model). ${ }^{12}$ The aerosol mass concentration predicted by the CATTBRAMS model accounts for advection, turbulent motion in the planetary boundary layer, convective transport by shallow and deep cumulus, wet and dry deposition and plume rise, among other effects. ${ }^{7,12}$ The spatial model domain was set up to encompass the entire South American continent. The horizontal model resolution was $48 \mathrm{~km}$ by $48 \mathrm{~km}$ over all of South America. The CATT-BRAMS model framework provided ground-based estimates of $\mathrm{PM}_{2.5}$ concentrations for each microregion in the Amazon region.

The Brazilian air pollution standards (CONAMA, $1990^{c}$ ) were established for protection of human health in urban areas. Brazil does not have a specific standard for $\mathrm{PM}_{2.5}$, although such a standard is under consideration by the Brazilian Institute for the Environment and Renewable Natural Resources (Instituto Brasileiro do Meio Ambiente e dos Recursos Naturais e Renováveis, IBAMA) and the National Environmental Council (Conselho Nacional de Meio Ambiente, CONAMA).

\footnotetext{
${ }^{a}$ Instituto Brasileiro de Geografia e Estatística. Sistema IBGE de Recuperação Automática. Contagem da população 2007. Brasília; 2007 [cited 2008 Oct 09]. Available from: http://www.sidra.ibge.gov.br/cd/default.asp

${ }^{b}$ Large-Scale Biosphere-Atmosphere Experiment in Amazonia Network. [cited 2008 Jun 20] Available from: http://lba.inpa.gov.br

c Conselho Nacional de Meio Ambiente. Resolução CONAMA nº 3, de 28 de junho de 1990. Dispõe sobre padrões de qualidade do ar, previstos no PRONAR. Diario Oficial Uniao. 22 ago 1990;Seção 1:15937-39.
} 
In the present study, the cutoff point of $80 \mu \mathrm{g} / \mathrm{m}^{3}$ was used: this level is considered "unhealthy" in the official standard legislation from the Oregon Department of Environmental Quality, in the United States, ${ }^{a}$ which is the only reference standard that is specific for biomass smoke.

The outcomes analyzed were the rates of hospitalization due to respiratory disease in children under five years old, elderly people over 64 years of age and other age groups, and due to childbirth. This last parameter was chosen for comparison, and to investigate whether there is any association between hospitalization due to birth and exposure to $\mathrm{PM}_{2.5}$. No association due to air pollution would be expected. Therefore, if some association were obtained, it would indicate the existence of problems with the exposure indicator or/and outcome databases.

The hospitalization rates were calculated as the number of hospital admissions due to RD, divided by the number of people in the age group and expressed as a percentage. Hospitalization due to childbirth was calculated as the number of hospital admissions due to childbirth or related complications, divided by the total female population between 15 and 45 years of age.

The database for the exposure indicator, i.e. the percentage of annual hours of $\mathrm{PM}_{25}$ above the limit of 80 $\mu \mathrm{g} / \mathrm{m}^{3}$, was produced by the Weather Forecasting and Climatic Study Center of the Brazilian Space Research Institute (Centro de Previsão de Tempo e Estudos Climáticos/Instituto Brasileiro de Pesquisas Espaciais, CPTEC/INPE). The hospitalization databases were obtained from the Brazilian Government's Hospital Information System and the Public Health System. Admissions due to respiratory causes were selected from Chapter $\mathrm{X}$ of the International Classification of Diseases (ICD-10). The population database was obtained from the Brazilian Institute of Geography and Statistics estimates. The rates for hospitalization due to childbirth were calculated from the number of such admissions given in Chapter XV of the ICD. In the Amazon region, most people exclusively use public health services, and the availability of records is an essential condition for the municipal government to receive federal funding.

The control variables were the mean number of blood tests (per 100 inhabitants) and the Human Development Indicator (HDI). The former was identified as an indirect indicator of health service quality, given that it is widely available and only requires simple technology. The database on the mean number of blood tests was available from the Ministry of Health. ${ }^{b}$ The data on the HDI (an overall measurement of human development based on a combination of educational, earned income and longevity data) were obtained from the United Nations Development Program. ${ }^{c}$

The variation coefficient was applied to investigate the variability of the exposure among the municipalities that belonged to each microregion. This measurement was calculated for the microregion by dividing the standard deviation of the $\mathrm{AH} \%$ by the mean of this indicator estimated for municipalities. The terciles of the exposure indicator were used as cutoff points for the exposure indicator, classified as low $(\leq 0.24 \%)$, medium $(0.24 \leq 3.70 \%)$ or high $(>3.7 \%)$. The biggest coefficients of variation represented microregions with great instability of exposure.

Box plots were also produced using the terciles of the exposure indicator. To analyze the variance of the outcome variables in relation to exposure levels, the Kruskal Wallis test was used, since this is appropriate for ordinary categories at the 5\% significance level.

The variables of $\mathrm{AH} \%$, hospital admission rates due to respiratory diseases (RD), and mean number of blood count tests were logarithmically transformed to normalize them. The variables of HDI and the rate of hospitalization due to childbirth were not transformed since they were found to be normally distributed.

The usual control variables based on meteorological data such as humidity, rainfall and temperature were also included in the CATT- BRAMS model outputs. Using the indicator $\mathrm{AH} \%$ of $\mathrm{PM}_{2.5}$, multiple regressions were applied to each of the four outcome variables, resulting in four distinct models calculated using by the SPSS statistical software version 16.0.

The study was approved by the Research Ethics Committee of Hospital Júlio Muller of the Federal University of Cuiabá.

\section{RESULTS}

Figure 1 shows the category of exposure in terms of the percentage of annual hours ( $\mathrm{AH} \%)$ of $\mathrm{PM}_{2.5}$, using the $80 \mu \mathrm{g} / \mathrm{m}^{3}$ threshold level and the coefficients of variation for the municipalities belonging to each microregion, in $2004-2005$. The microregions with high levels of exposure were similar in 2004 and 2005. Differences in exposure level were found in the state of Acre and in southern Amazonas, thus indicating the arc of forest degradation. The big circles in Figure 1 are

\footnotetext{
a Oregon Department of Environmental Quality. [cited 2008 Feb 02] Available from: http://www.deq.state.or.us/aqi/index.aspx

b Ministério da Saúde. Departamento de Informática do Sistema Único de Saúde. [Internet]. Brasília; c1991 [cited 2008 Mar 23 ]. Available

from: www.datasus.gov.br

c Programa das Nações Unidas para o Desenvolvimento. Atlas do desenvolvimento humano. Rio de Janeiro; c2000 [cited 2008 Apr 15].

Available from: www.pnud.org.br/atlas/
} 


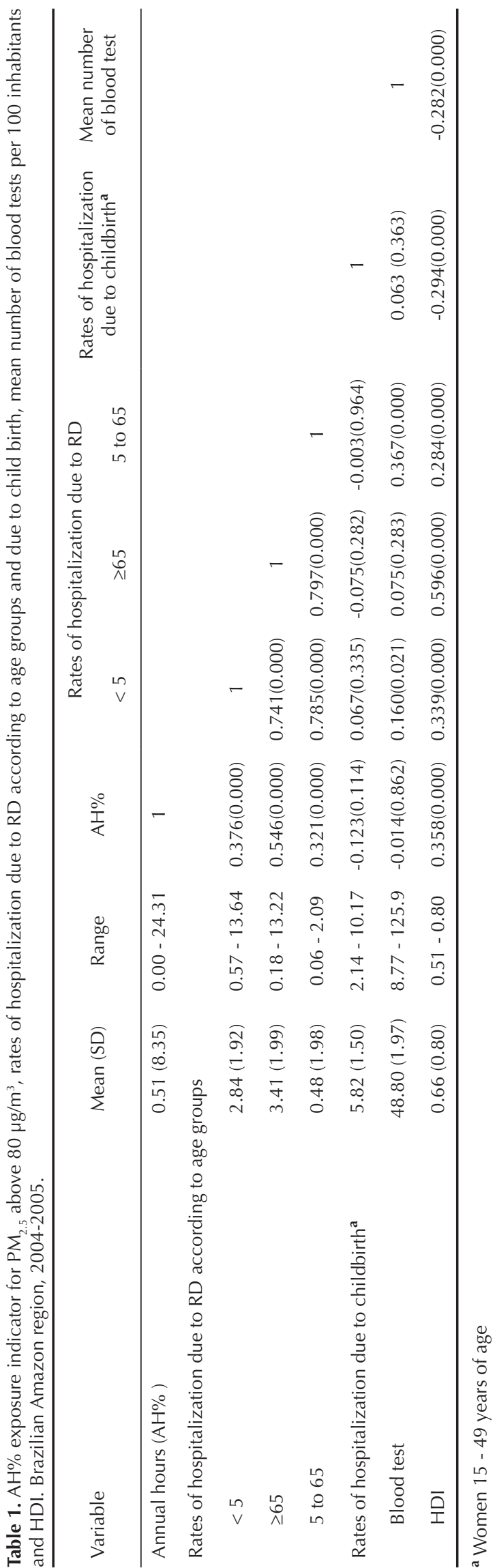

visible mainly towards the east, throughout the states of Tocantins and Maranhão, and in northern Amazonas.

Microregions with high exposure levels also presented smaller variation coefficients. Thus, high-level exposure remained stable inside those regions. The coefficients of variation appeared to be inversely proportional to exposure levels, which implied a certain degree of homogeneity of the spatial distribution of $\mathrm{PM}_{2.5}$ inside micro regions.

The rates of hospital admissions due to $\mathrm{RD}$ for children and the elderly were similar, reaching a maximum of $13 \%$, whereas these rates did not exceed $2 \%$ for individuals between five and 65 years old (Table 1). For
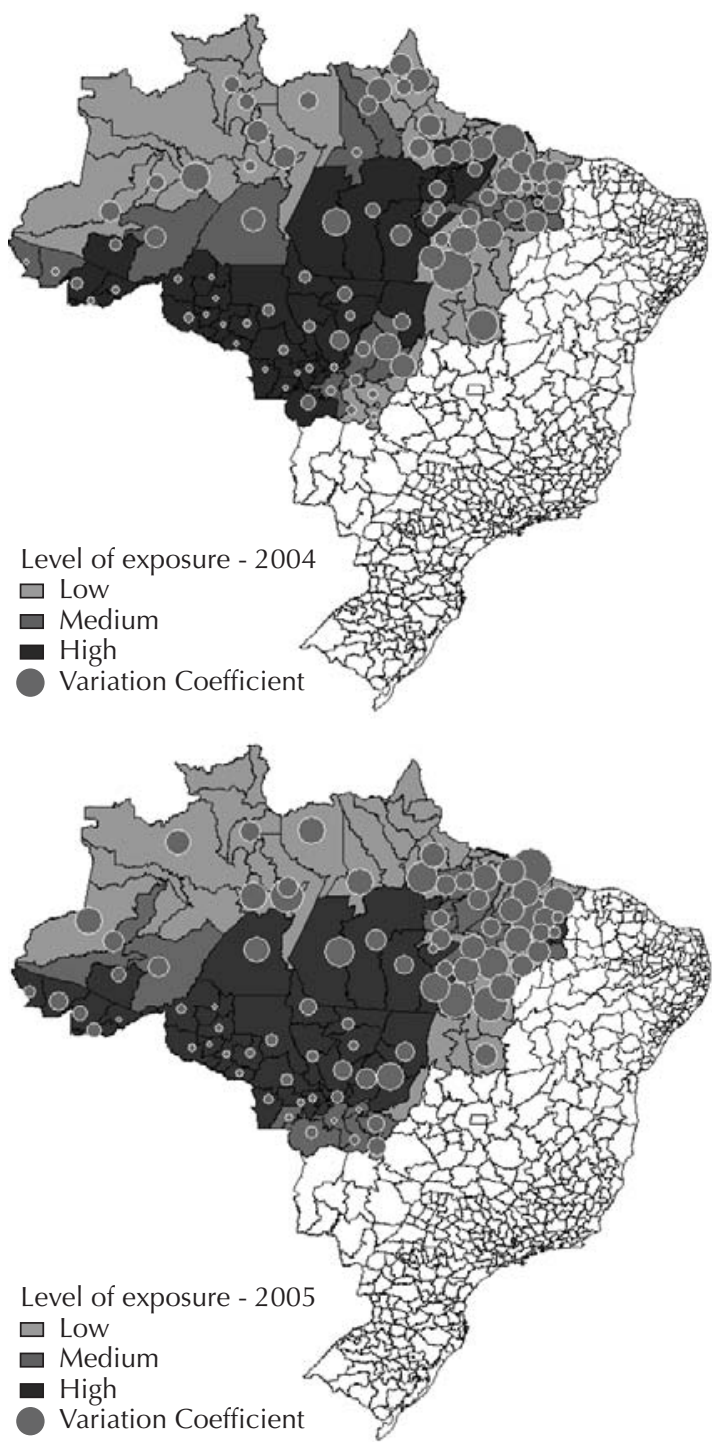

Figure 1. Exposure levels in terms of percentage of annual hours $\left(\mathrm{AH} \%\right.$ ) of $\mathrm{PM}_{25}$ above $80 \mu \mathrm{g} / \mathrm{m}^{3}$ and variation coefficient among the municipalities belonging to the microregions. Brazilian Amazon region, 2004 - 2005. 
Table 2. Comparison of the mean rates of hospitalization due to respiratory diseases according to age groups and rates of hospitalization due to childbirth with terciles of the $\mathrm{AH} \%$ exposure indicator for $\mathrm{PM}_{2.5}$ above $80 \mu \mathrm{g} / \mathrm{m}^{3}$. Brazilian Amazon region, 2004-2005.

\begin{tabular}{lcccc}
\hline $\begin{array}{l}\text { Mean rates of hospital admissions } \\
\text { / Level of exposure }\end{array}$ & $\begin{array}{c}\text { Low } \\
95 \% \mathrm{Cl}\end{array}$ & $\begin{array}{c}\text { Medium } \\
95 \% \mathrm{Cl}\end{array}$ & $\begin{array}{c}\text { High } \\
95 \% \mathrm{Cl}\end{array}$ & $\begin{array}{c}\text { Chi-square }^{\mathrm{a}} \\
(\mathrm{p} \text {-value })\end{array}$ \\
\hline Due to RD $<5$ year of age & $2.28(1.94 ; 2.68)$ & $3.26(2.81 ; 3.78)$ & $3.90(3.37 ; 4.52)$ & $22.1(0.000)$ \\
Due to RD $\geq 65$ year of age & $2.61(2.26 ; 3.02)$ & $3.69(3.14 ; 4.32)$ & $5.76(4.91 ; 6.76)$ & $41.38(0.000)$ \\
Due to RD 5 to 64 year of age & $0.42(0.36 ; 0.51)$ & $0.53(0.45 ; 0.62)$ & $0.66(0.56 ; 0.78)$ & $16.17(0.000)$ \\
Due to childbirth & $6.13(5.49 ; 6.36)$ & $5.55(5.77 ; 6.49)$ & $5.87(5.13 ; 5.97)$ & $6.01(0.050)$ \\
\hline
\end{tabular}

a Kruskal-Wallis test

hospital deliveries, the rates varied from $2 \%$ to $10 \%$ in the 15 to 45 -year-old groups. There was significant variation in the mean number of blood count tests, ranging from nine to 126 tests per 100 inhabitants per year. The highest observed value for the HDI was almost $40 \%$ greater than the lowest.

The correlation coefficients (Table 1) were significant for $\mathrm{AH} \%$ and the rates of hospital admission due to $\mathrm{RD}$, for all age groups, and the largest correlation was for the elderly $(\mathrm{r}=0.55 ; \mathrm{p}<0.000)$, in comparison with the other age groups. The rates of hospital admission due to childbirth were only correlated with the HDI.

Figure 2 shows the distribution of the rate of hospitalization due to $\mathrm{RD}$ for the various age groups, and the rate of hospitalization due to childbirth, with the respective medians, according to terciles of levels of $\mathrm{PM}_{2.5}$ above $80 \mu \mathrm{g} / \mathrm{m}^{3}$, expressed as $\mathrm{AH} \%$. The highest terciles of exposure were associated with the highest rates of hospitalization for all age groups, and children and the elderly registered the highest rates of hospitalization due to RD. On the other hand, as expected, the variation in the rates of hospitalization due to childbirth did not present the same relationship with $\mathrm{PM}_{2.5}$ exposure as shown by the rates of hospitalization due to RD.

The comparison of mean hospitalization rates presented statistical significance for all dependent variables tested, with regard to the level of exposure by terciles (Table 2). For the children hospitalized due to $\mathrm{RD}$, the mean rates ranged from $2.3 \%$ to $3.9 \%$. For the elderly, the increase in hospitalization rates ranged from $2.6 \%$ to $5.8 \%$. For the intermediate age group, hospital admission rates ranged from $0.4 \%$ to $0.7 \%$. The results from the Kruskal-Wallis test were significant at the level of $5 \%$. The mean hospitalization rates due to childbirth showed fluctuation, which decreased from the low to medium level, and increased from the medium to high level. The confidence intervals were similar, with high overlap.

Table 3 presents the multiple regressions on the hospitalization rates due to RD among children, elderly people and the intermediate age group, and in relation to childbirth. In this table, the predictive variables are the percentage of annual hours of $\mathrm{PM}_{2.5}(\mathrm{AH} \%)$, Human Development Index (HDI) and percentage of blood tests in the Amazon region, for the study area during 2004 and 2005.

The best determination coefficient $\left(\mathrm{r}^{2}\right)$ was found in the model for the elderly and the rate of hospitalization due to $\mathrm{RD}(59 \%)$, and the worst was for the rate of hospitalization due to childbirth (16\%). From the models for children, the elderly, and the intermediate age group, with regard to the rate of hospitalization due to $\mathrm{RD}$, the significance of the exposure indicator (AH\%), HDI and blood count tests can be seen.

Table 3. Multiple regression on rates of hospitalization due to RD according to age groups and due to childbirth, with predictive variables: $\mathrm{AH} \%$ of $\mathrm{PM}_{2.5}$ above $80 \mu \mathrm{g} / \mathrm{m}^{3}$, Human Development Index (HDI) and mean number of blood count tests. Brazilian Amazon region, 2004-2005.

\begin{tabular}{|c|c|c|c|c|}
\hline Variable & $\begin{array}{c}<5 \text { years of age } \\
(\text { RD) } \\
(p-\text {-value })\end{array}$ & $\begin{array}{c}\geq 65 \text { years of age } \\
\text { (RD) } \\
\text { (p-value) }\end{array}$ & $\begin{array}{c}5 \text { to } 65 \text { years of age } \\
\text { (RD) } \\
\text { (p-value) }\end{array}$ & $\begin{array}{c}\text { Women } 15-49 \text { years } \\
\text { of age (birth) } \\
\text { (p-value) }\end{array}$ \\
\hline $\mathrm{R}^{2}$ & $0.232(0.481)$ & 0.587 & 0.320 & 0.158 \\
\hline (R) & & $(0.766)$ & $(0.565)$ & $(0.398)$ \\
\hline Constant & $-1.25(0.030)$ & $-3.17(0.000)$ & $-4.52(0.000)$ & $11.45(0.000)$ \\
\hline Exposure (AH \%) & $0.076(0.001)$ & $0.101(0.000)$ & $0.052(0.017)$ & $-0.003(0.953)$ \\
\hline HDI & $2.51(0.000)$ & $5.51(0.000)$ & $3.69(0.000)$ & $-8.537(0.000)$ \\
\hline Blood count & $0.195(0.004)$ & $0.235(0.000)$ & $0.376(0.000)$ & $0.026(0.882)$ \\
\hline
\end{tabular}


The association of the exposure indicator was higher for the elderly than for other age groups $(\beta=0.10)$. For each $1 \%$ increase in the exposure indicator, there was an increase of $8 \%$ in the rate of child hospitalization and $10 \%$ in hospitalization of the elderly.

The fourth model, indicating the rate of hospitalization due to childbirth, shows the HDI as the predictive variables with significant results. No association was found between the exposure indicator ( $\mathrm{AH} \%$ ) and the rate of hospitalization due to childbirth, even when adjusted for the control variables HDI and blood count test.

The HDI showed significant associations with all the endpoints analyzed. This control variable indirectly indicates differences in terms of the population's quality of life. Nevertheless, there seemed to be an inverse correlation between hospitalization due to RD and due to childbirth. For the former, the HDI and rates of admission were directly proportional. However, for the latter, the greater the HDI was, the smaller the rate of hospitalization due to childbirth was, i.e. they were inversely proportional.

\section{DISCUSSION}

The present study is one of the first to evaluate the exposure indicators by analyzing the impacts on human health of exposure to particulate matter emissions $\left(\mathrm{PM}_{2.5}\right)$ from biomass burning in the Brazilian Amazon region. The use of $\mathrm{PM}_{2.5}$ predicted by numerical air quality model is an innovative approach that was a feasible alternative to the traditional air quality monitoring network.

The percentage of annual hours of $\mathrm{PM}_{2.5}$, used as an indicator of atmospheric pollution in the Brazilian Amazon region, showed an association with the occurrence of RD, especially in the more vulnerable age groups (elderly people and children under five years of age). The results from this study agree with the literature ${ }^{5,17}$ with regard to the effects of particulate matter on hospitalization rates.
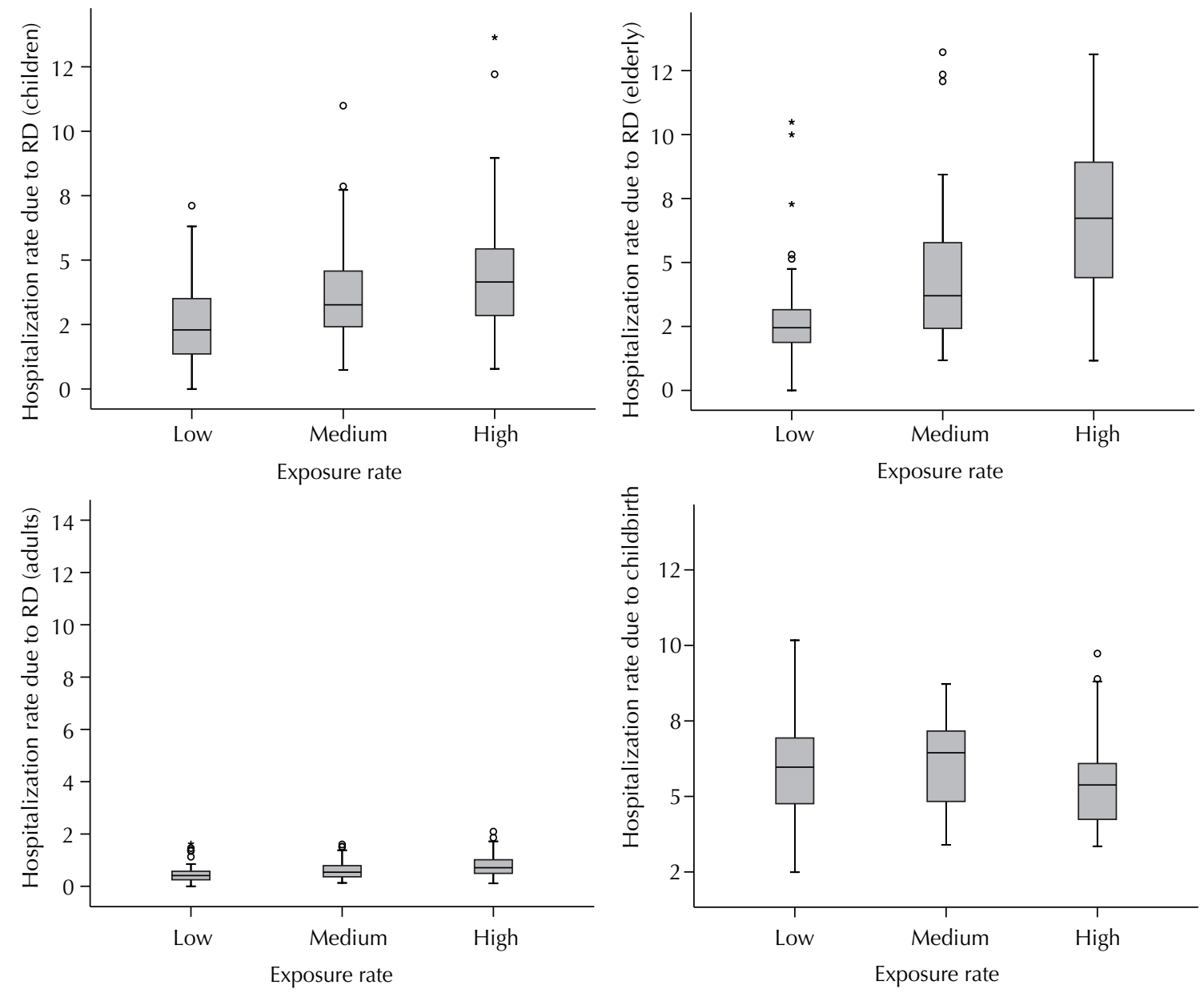

Figure 2. Rate of hospitalization due to RD according to age groups and due to childbirth with terciles of the exposure indicator of the percentage of annual hours ( $\mathrm{AH} \%$ ) of $\mathrm{PM}_{2.5}$ above $80 \mu \mathrm{g} / \mathrm{m}^{3}$. Brazilian Amazon region, 2004-2005. 
Haller et $\mathrm{al}^{10}$ argued that a frontier like the Amazon region entails the existence of a sparsely inhabited geographical area, equipped with weak and fragmented institutions. It is likely that accelerated occupation of frontier regions imposes demands on the health services that are difficult to meet. According to Porto, ${ }^{19}$ such conditions refer to a development model that is unfair, particularly on the poorest portions of the population. The significant merit of environmental justice can be seen in the influence of social conditions on vulnerability to respiratory diseases, as represented by the HDI. Marandola \& Hogan ${ }^{13}$ considered vulnerability to be of a social, environmental and technological order. It can be considered that, in addition to the limited State role in the field of healthcare, the social conditions of the environment interfere and thus generate a degree of social inequality and, consequently, individual and collective vulnerability.

As expected, the $\mathrm{AH} \%$ indicator did not show an association with the hospitalization rates due to childbirth. The hospital delivery rate would not be expected to be influenced by exposure to air pollution. In areas with poor health services, the local population has difficulty in accessing hospitals and health services in general. In the Amazon region, it is likely that in some areas, pregnant women seek help in the local community at the time of delivery, rather than go to a hospital. The HDI control variable indirectly indicates differences in terms of the population's quality of life, and it showed significant associations with all the endpoints analyzed. The mean number of blood count tests reflects the accessibility and quality of basic health services. The hospital delivery rate seems to be a satisfactory comparison variable, since it was adjusted for the control variables of HDI and blood count test. In this way, bias in the choice of the comparison variable with RD was avoided.

The World Health Organization has established that the annual limit for $\mathrm{PM}_{2.5}$ is a mean of $10 \mu \mathrm{g} / \mathrm{m}^{3}$ and a daily mean of $25 \mu \mathrm{g} / \mathrm{m}^{3}$ for urban areas, ${ }^{23}$ without distinguishing the types of emission and the types of exposure (chronic or acute). In the Brazilian Amazon region, the resident population is exposed to air pollution for a short period of time, compared with the population of urban or industrial areas. Nevertheless, it has to be borne in mind that $\mathrm{PM}_{2.5}$ from biomass smoke can represent $60 \%$ of the $\mathrm{PM}_{10} \cdot{ }^{9}$ Some municipalities monitored by the LBA Millennium Institute network in the Amazon region showed frequently measurements of $\mathrm{PM}_{2.5}$ above $240 \mu \mathrm{g} / \mathrm{m}^{3}$ during the study period. The size of the particles is of considerable significance for human health. Fine particles are detrimental to health because of inhalation and penetration deep into the lungs. ${ }^{16}$ This physiological mechanism, combined with high levels of exposure may explain the existence of many cases of respiratory disease in vulnerable age groups such as children and the elderly ${ }^{18,6}$ in many municipalities in the Amazon region.

In contrast to the large amount of information correlating urban PM with human health impacts, there are a limited number of studies evaluating the impact on community health of air pollution resulting from the burning of biomass. Some papers have discussed the impact on human health of the pollutants from wood smoke, and, more recently, sugarcane smoke., 5 In the case of the Amazon region population, it is important to note that during the rainy season there is no air pollution, except some biogenic particles in the atmosphere. ${ }^{18}$ On the other hand, the studies on air pollution in conjunction with the sugarcane harvest were conducted in southeastern Brazil, which has also many industries and a lot of vehicles, thus resulting in some air pollution at all times of the year. It suggests that in urban southeastern Brazil, the population may have higher physiological resilience and more tolerance to exposures than shown by the Amazon region population.

This study contrasts with the customary time-series studies because it allowed analysis of spatial units with different exposure rates. Time-series, which demand other exposure measurements, such as daily averages for $\mathrm{PM}_{2.5}$ and outcome, are absolutely relevant as a tool for identifying the relative risk. Therefore, using this indicator was instrumental for obtaining an overview of the exposure to $\mathrm{PM}_{2.5}$ in the Brazilian Amazon region.

The aggregation of the exposure measurements as the mean percentage of annual hours for each microregion excluded the variability of the proportions in each municipality. This is important especially in the eastern Amazon region (State of Pará), where the forest burning is intense. On the other hand, as the wind blows from the Atlantic region to the western side of the Amazon region, it results in dispersion and transportation of the smoke from the point source of the burning to faraway areas. $^{6}$ This indicator, calculated in terms of hours, enabled investigation of the magnitude of the exposure as a percentage, taking into account the dispersion and the transportation of the particulate matter.

The magnitude of the exposure to biomass burning during 2004 and 2005 was significantly lower than during the previous four to five years. ${ }^{a}$ This could be attributed to the international pressure relating to Brazil's role in the scenario of biomass burning, and to national policies for controlling deforestation. The results from this study may be considered to be a tool

a Ministério da Ciência e Tecnologia. Projeto PRODES. Monitoramento da Floresta Amazônica Brasileira por Satélite. Brasília; c2008 [cited 2008 Feb 10]. Available from: http://www.obt.inpe.br/prodes/ 
for surveillance of environmental health in the Amazon region, and for application to estimates of the financial costs of this exposure for the health services. However, the limitation of this study relates to the way in which the indicator was proposed. It is a single measurement per year, representing the exposure to $\mathrm{PM}_{2.5}$, which means loss of variability, thus making dose-response analysis unviable.

The decision to perform analyses throughout the year, and not only on data from the dry season was justified by the differences among the microregions regarding the beginning of the dry season and forest burning, which is not the same for all areas. Since the Amazon region is divided by the Equator line, it has distinct seasonal climates. While the area north of the Equator is in a dry season, the area south of the Equator would be experiencing heavy rain. In addition, there are some intermediate unstable rainy periods in both areas.

This new methodological approach showed the capability to differentiate categories of exposure with regard to air pollution in the Amazon region. In conclusion, the percentage of annual hours of $\mathrm{PM}_{2.5}$, as an indicator of atmospheric pollution in the Brazilian Amazon region, showed an association with occurrences of RD, especially in the more vulnerable groups. This indicator reflects differences in exposure to atmospheric pollutants and, therefore, opens up new perspectives for dealing with the effects of forest burning on human health. 


\section{REFERENCES}

1. Anderson HR, Ponce de Leon A, Bland JM, Bower JS, Strachan DP. Air pollution and daily mortality in London: 1987-92. BMJ. 1996;312(7032):665-69.

2. Andreae M, Artaxo P, Fischer H, Freitas SR. Grégoire J-M, Hansel A, et al. Transport of biomass burning smoke to the upper troposphere by deep convection in the equatorial region. Geophys Res Lett. 2001;28(6):951-4. DOI:10.1029/2000GL012391

3. Artaxo P, Martins JV, Yamasoe MA, Procópio AS, Pauliquevis TM, Andreae MO, et al. Physical and chemical properties of aerosols in the wet and dry season in Rondônia, Amazonia. J Geophys Res. 2002;107(D20):8081-95. DOI:10.1029/2001JD000666

4. Artaxo P, Gatti LV, Leal AMC, Longo KM, Freitas SR, Lara LL, et al. Química atmosférica na Amazônia: a floresta e as emissões de queimadas controlando a composição da atmosfera amazônica. Acta Amaz. 2005;35(2):185-96. DOI: 10.1590/S004459672005000200008

5. Cançado JE, Saldiva PH, Pereira LA, Lara LB, Artaxo $P$, Martinelli LA. The impact of sugar cane-burning emissions on the respiratory system of children and elderly. Environ Health Perspect. 2006;114(5):725-9.

6. Freitas SR, Longo KM, Silva Dias MA, Silva Dias PL. Emissões de queimadas em ecossistemas da América do Sul. Estud Av. 2005;19(53):167-85. DOI:10.1590/ S0103-40142005000100011

7. Freitas SR, Longo KM, Dias MAFS, Chatfield R, Dias PLS, Artaxo P, et al. The Coupled Aerosol and Tracer Transport model to the Brazilian developments on the Regional Atmospheric Modeling System (CATTBRAMS). Part 1: Model description and evaluation. Atmos Chem Phys Discuss. 2007;7:8525-69.

8. Gouveia N, Mendonça GAS, Ponce-de-Leon A, Correia JEM, Junger WL, Freitas CU, et al. Poluição do ar e efeitos na saúde nas populações de duas grandes metrópoles brasileiras. Epidemiol Serv Saude. 2003;12(1):29-40.

9. Hacon S, Artaxo P, Gerab F, Yamasoe MA, Campos RC, Conti LF, et al. Atmospheric mercury and trace elements in the region of Alta Floresta in the Amazon basin. Water Air Soil Poll. 1995;80(1-4):273-83. DOI:10.1007/BF01189677

10. Haller AO, Torrecilha RS, Haller MCDP, Tourinho MM. Os níveis de desenvolvimento socioeconômico da população da Amazônia brasileira - 1970 e 1980. Hist Cienc Saude-Manguinhos. 2000;6(Supl):941-73. DOI:10.1590/S0104-59702000000500010

11. Hyesook P, Boeun L, Eun-Hee HA, Jong-Tae L, Ho K, Yun-Chul H. Association of air pollution with school absenteeism due to illness. Arch Pediatr Adolesc Med. 2002;156(12):1235-9.
12. Longo KM, Freitas SR, Setzer A, Prins E, Artaxo $\mathrm{P}$, Andreae MO. The Coupled Aerosol and Tracer Transport model to the Brazilian developments on the Regional Atmospheric Modeling System (CATTBRAMS). Part 2: Model sensitivity to the biomass burning inventories. Atmos Chem Phys Discuss. 2007;7:8571-96.

13. Marandola E, Hogan HJ. Dimensões da vulnerabilidade. São Paulo em Perspectiva. 2006;20(1):33-43.

14. Martins LC, Latorre MRDO, Cardoso MRA, Gonçalves FLT, Saldiva PHN, Braga ALF. Poluição atmosférica e atendimentos por pneumonia e gripe em São Paulo, Brasil. Rev Saude Publica. 2002;36(1):88-94. DOI:10.1590/S0034-89102002000100014

15. Mascarenhas MDM, Vieira LC, Lanzieri TM, Leal APPR, Duarte AF, Hatch DL. Poluição atmosférica devido à queima de biomassa florestal e atendimentos de emergência por doença respiratória em Rio Branco, Brasil - setembro, 2005. J Bras Pneumol. 2008;34(1):42-6. DOI:10.1590/S180637132008000100008

16. Nel A. Atmosphere. Air Pollution-related illness: effects of particles. Science. 2005;308(5723):804-6. DOI:10.1126/science.1108752

17. Organización Panamericana de la Salud. Evaluación de los efectos de la contaminación del aire en la salud América Latina y el Caribe. Washington; 2005.

18. Pauliquevis T, Artaxo P, Oliveira PH, Paixão M. O papel das partículas de aerossol no funcionamento do ecossistema amazônico. Cienc Cult. 2007;59(3):48-50.

19. Porto MF. Saúde do trabalhador e o desafio ambiental: contribuições do enfoque ecossocial, da ecologia política e do movimento pela justiça ambiental. Cienc Saude Coletiva. 2005;10(4):829-39. DOI:10.1590/ S1413-81232005000400008

20. Pope CA, Dockery DW, Spengler JD, Raizenne ME. Respiratory Health and Pm10 Pollution - A Daily Time-Series Analysis. Am Rev Respir Dis. 1991;144(3):668-74.

21. Prins EM, Feltz JM, Menzel WP, Ward DE. An Overview of GOES-8 Diurnal Fire and Smoke Results for SCAR-B and 1995 Fire Season in South America. J Geophys Res. 1998;113(D24):31821-35. DOI:10.1029/98JD01720

22. Spektor DM, Hofmeister VA, Artaxo P, Brague JA, Echelar F, Nogueira D. P. et al. Effects of heavy industrial pollution on respiratory function in the children of Cubatão, Brazil: a preliminary report. Environ Health Perspect. 1991;94:51-4. DOI:10.2307/3431292

23. World Health Organization. Air quality guidelines: global update. Geneva; 2005.

Research supported by Conselho Nacional de Desenvolvimento Científico e Tecnológico (CNPq, Process N. 420199/2005-5), Fundação de Amparo à Pesquisa do Estado de Mato Grosso/Departamento de Ciência e Tecnologia do Ministério da Saúde (FAPEMAT/DECIT, N. 10037682/2006).

Study presented in the 18th IEA World Congress of Epidemiology, Porto Alegre, Southern Brazil, on September 21, 2008. 